vations, taken the trouble of digesting and arranging the whole, and rejecting the extraneous matter, the book would certainly have been much reduced in size, but it would have been greatly increased in value. As it is, the labour of perusing it will scarcely be adequately rewarded by a lnowledge of the scattered information which it contains.

\section{TREATMENT OF SNAKE BITES.}

\section{By J. Ha scock, M.D., London.}

\section{To the Editor of The LANCET.}

Srn, -Upon reading in the last number of THE LANCEr, the interesting statements given by Mr. Duncan (at a meeting of the Westminster Society), respecting the Minghoos, and the autidotes to the bites of venomous serpents in India, I was so struck with its analogy or coincidence with what has been related to me in South America, in parts so distant, as opposite as the antipodes, I could not forbear offering you the following account from my manuscript, which possibly you may deem worthy of attention, especially as the subject of antidotes is so little understood, and the treatment of course so vacillating and effete.

\section{I am, Sir,}

Your very obedient Servant, J. HA NCOCK.

London, 24th Feb., 1830.

IN South America, where I resided for twenty-five years, and where venomous serpents are very numerous, a free use of the guaco infused in rum or other spirit, is generally esteemed as the best remedy for the bites of poisonous serpents, taken in. wardly and applied to the wound. It doubtless is one of the most potent usually at hand. It must be noticed, however, that the guaco here alluded to is not the composite, micuria guaco of Mutis and Humboldt, a plant nearly insipid, but a species, or rather several species, of strong aromatic bitter aristolochias which grow in Orinoko, and in various parts of Guiana.

Don Ventura Gomez (a great saranero) related to me, at Angostura, in 1816, an instance he had witnessed of a man (one I had just attended in fever), whom he saw with his own eyes, as he expressed it, take up a cascabel or rattle-snake, and put it in his bosom, catching it while irritated and in a most savage state. The serpent, on being taken up by this man, seemed in a half tor. pid or lethargic state, made feeble attempts to bite, and did bite his hand slightly while wreathing about his arm.*

He had been told previous to this, by Don Andreas Condi, of the ability or strange talent of this man, whowas prepared with the guaco by: a Doctor in Santa Fé.

Dr. Habila also rave me the same account of this man (named Narcos). "This mon," says the Rev. Doctor, "was inoculated with the guaco, by a hrother of the celebrated Mutis of Santa Fé." He explained the term inoculado in this way, that the man drank a small possim of the guaco for nine mornings, observing a ppare and rigid diot, premising purges.

The Doctor related a most extraordinary feat performed by this man upon a serpest, which he saw himself, it was a rattle-smake. I should have passed this unnoticed, had I not known the character of my informer. He met Marcos at the door of Condi, at Angostura, and observed by the side of him, a wild and ferocious rattle-snake, which Marcos immediately took up, wound about his hand, and afterwards put into his bo. som. He pretended at first it was doue by some mysterious prayers and incantations; but the Dr, treating it as folly and affirm. ing the effect of guaco, he afterwards con. fessed it to be true. He stated that he was cured, as he termed it, in the manner before related,- that he was young, and his father being under cure with guaco, caused him to enter on the same, for it is a most common practice in those parts of Santa Fé and Caraccas, to " cure," or prepare those who are to be exposed to the bites of renomous serpents. Some estates in Caraccas, 1 was told, have all their negroes, and even their horses and cattle, so prepared. This serpent would spring witb violence at any cne elsa; but with Marcos seemed torpid and lethargic. At length he let the snahe loose in the yard; but it soon died, as of the poison he bad imbibed from his master.

The Doctor saw the man also handle a water snake, Culebra de Agua (a boa, and of course not poisonous), at Tocoma in a surprising manner, allowing it to wreatlie around his arms and body, for the snake be observed was three varas, or nine feet in length. This, as well as the rattle-snake, made, he says, slight efforts to bite, but without any effect; and an Englishman pre. sent, seeing how Marcos managed the mon. ster, was bold enough to make a trial of it himself; but the snake seized him by the thumb which he split asunder, and he (the Dr.) assisted to pick the eyes out of the monster's head, before he could be made to let go.

* I remarked that, perbaps the fangs were drawn, but he most positively asserted the contrary. 
This man (the Englishman) was one of by the mouth, both before and after scarifithe crew of the Hermoine who murdered cation, and pressing the wound from the their officers, going into Carthagena, about bottom, with the assistance of the teeth and thrry or forty years ago. He is a carpen- and fingers, ${ }^{*}$ is the secret which alone is ter, a man of quiet and pacific character, requisite to be attended to for the removal and yoes by the name of Don Carlos.

The man was soon after this in Angos. tura, wlile besieged by the patriots. He ras a cabin-boy in the Hermoine frigate at the time of the foremantioned massacre. He appeared to be about forty years of age ; and ras married to a relation of Dr. Habila. He has a family, but lost his wife and one or two chuldren in the general pestilence of 1817. I must confess my slowness of faith levertofore, with respect to details like the foregoing, although from persons of undoubted veracity-yet, like all of us, liable to the fallacies of the senses; and I should never, perhaps, have thought of offering the present notices for publication, but from the extraordinary case stated last week in $\mathrm{T}_{\mathrm{H}}$ : LANCET, and the singular coincidence herein described.

The mato, a large species of lacerta, ${ }^{*}$ is said by the Spaniards to be a great enemy to serpents, and that it cures itself when bitten by eating of the raiz del mato, an aristolochia, so called from this circumstance, and considered an excellent antidote, as is a!so a certain narcotic plant, called artcari by the Gnaynos, a kind of Spigelia, not well defined by the botanists, but of the gentiana family; the fresh plant is bruised, and its juice squeezed into the patient's mouth, and wound ; or, if dry, a strong infusion in boiling water.

It is worthy of remark, that of the numerous class of American remedies for the bites of serpents, nearly all of them are substances of a very hot and stimulant nature, at least those of the vegetable kind.

For the deadily poisons of the different serpents of South America, the most potent esclarotics should be immediately applied. The most powerful and efficacious of all, perlaps, is the nitrate of mercury.

But as first and paramount to all other remelies, suction should be employed and persisted in, together with scarification to the full depth of the wound. Strong exugation is not required. A continued suction

* This lizard belongs to the section of the monitors, of which there are several undesenbed species and varieties; it grows to two or three feet in length; its back is flat, and marked with singular yellow figures on a glossy black ground. It appears the same ss that called salempenter in Demerara, and, 1.the that animal, has the power of running 60: a snall distance upon the surface of the wator, and thus crossing small streams or candls, on which, when alarmed, it scampers rarialy with much noise and strepitus. lieve, than the cupping-glass, from the assistance given by the hands and teeth.

Being, in 1814, on an excursion up the Rio Caroni, at a dwelling of the Caribee Indians, one of my attendants, of the Guayana tribe, was bit in the calf of the leg by the large kind of labaria serpent (Mapanari) which was boldly killed on the spot by the man bitten. This is one of the most poison: ous serpents, little inferior to the quaima and rattle-snake. It happened near the house where I was; and I saw him presently, perhaps in eight or ten minutes after the bite, the limb had already swelled, nearly to the groin; he complained of great pain, and made many efforts to romit-had a wild aspect, bordering on delirium. I instantly scarified the wound freely with a lancet I had in my pocket, squeezed it and wiped off the blood, and desired the natives to suck it; they refused, as did also my black sersant, who significantly shook his head, saying to me, "No, massa; I do every ting for please you, but I no do dat, it shall kill me one time." I made no ceremony, but applied my mouth and sucked it; at the same time deeply grasping the wound with my fingers, working or squeezing it up from the bottom; occasionally washing my mouth with water, not from any apprehension of the poison, but merely to obviate, somewhat, the repugnance one is apt to feel. I continued the exugation for some time, and telling the Indians the poison was all extracted, one of them mustered courage to assist me, for the muscles of the tongue soon became fatigued by the exercise. I had in the mean time caused the patient to swallow about two grains of opium, for although not. an opium-eater, I seldom travelled without a piece in my pocket, as well as emetic tartar, and a lanct ; with this tery portable apparatus, I considered myself not ill-prepared to meet the effects of both the animal and vegetable poisons abounding in these forests, where nature elaborates the most potent poisons, as well as antidotes. The absorption was arrested, and the patient soon after slept for some hours. The limb remained much tumefied, as the absorption of the virus had proceeded to no small extent before I saw him. However, by the use of warm, aromatic perspiratives, tisans of haiowabally (a nondescript composite),

* This also is the method practised by some inland nations of South America, and who are the only ones that attempt the cure of snake-bites. 
and the careru (aristolochia longifolia), the tumefaction and all bad symptoms subsided in a few days. I neglected to apply a ligature in this case, although it is a precau. tionary measure of great importance, as a handkerchief or cord of any kind, to be twisted with a stick just above the bite. We must recollect that tourniquets, cupping. glasses, \&c. are rarely to be had in situations where these accidents occur. The ligature, at the same time that it impedes the progress of the virus towards the vital parts, promotes a flow of blood from the scarified wound, and greatly facilitates the ejection of the poison.

I may add, I never saw ammonia tried; I was told in 1804, by Dr. Tuite, a physician of long experience in the colonies, that he was fully convinced from trials, it was quite unavailing. The fact is, amongst thousands of reputed antidotes, there are absolutely none to be depended on as prev'entive, except suction and scarifying; ; and, for obviating the effects of their absorption, opium and the class of warm alexipharmics.

Most unhappily, a superstitious dread prevails against the only certain remedy, not only amongst the natives, but Europeans also, from a fear of imbibing the poison by the mouth, and that too, I am sorry to say, oven amongst many of the medical faculty.

RESPIRATION AFTER PERFOHATION OF ROTH SIDES OF THE THORAX.

\section{To the Editor of The Lancet.}

Sir,-The correspondent who under the signature of A. S. addressed you last week (see number 338 ) upon the subject of wounds penetrating both sides of the thorax, may be excused for his erroneous conception of the authority he cites, upon the plea of wanting access to those sources from which a treacherous memory may derive renovation; but as the subject is one of some physiological importance, you will, perhaps, permit me to place in a correct point of view before your

* And these are, I may almost say, infal. lible, even against the most venomous bites, if applied instantly after the wound is in. ficted; unless a vessel of some size be punctured.

1 have recently seen an account corrobo. rative of this method, in a Boston paper; it is as follows:- "The proprietor of a collection of rattle-snakes exhrbiting at Boston was bitten by one of them. A friend immediately cut the wound, and applied his mouth to suck out the poison; sweet oil was given to the man, and applied to the wound, and the swelling subsided." readers, the conclusions which the experiments reported by Van Swieten tend to es* tablish.

The passage from Dr. Arnot's book, which forms the basis of his remarks, will be found at page 544 of his (1)r. A.'s) volume, in the following words:-

"If such wounds, therefore, (wounds penetrating the pleura,) were made into both sides of the chest at once, even without hurting any part within, the person wonld still die of suffocation, because all the lungs would remain collapsed."

The author here states as a fact of universal occurrence, that which is only true under certain circumstances; and from, the writings of Van Swieten it appears that he also, prior to his acquaintance with a Dr. William Houstoun, by whom the following experiments were suggested, laboured under a similar mistake; for when his frend pat the question to him, whether wounds of both sides of the chest were necessarily fatal, he answered in the affirmative, and was much surprised by his producing a dog, upon whicb the operations had been done three days before and which then " $x a n$ about as if nothing ailed it," although the wounds.bad entered the chest, and the openings were unobstructer by any adhesions of the lungs, as he at first suspected.

Similar results were obtained in several nther trials; in some, air was blown in at the wounds; in others, the abdomen was opened, and the diaphragm wounded on one, or both sides; and in one the trachea was cut across; In these cases the continuance of life varied from fifteen minutes to three hours.

When ag ain the incisions were very large, running yarallel betwixt the ribs, half the length of one's finger or more, then the animals quickly expired; but (says Van Swieten) " the hæmorrbage was always very profuse." Conversing with lis friends on the cause of these singular and unexpected phenomena, they came to the following opinion.

"That if the wounds inflicted had a less aperture than the rima of the glottis, then the air meeting with an easier passage through the aperture of the glottis than through the wounds, would distend the lungs-and the reverse."

To verify this opinion experimentally, tubes with apertures larger than that of the glottis in the animal, were inserred into the wound; by this means they were retained open, and "respiration instantfy ceased, the voice was lost, and the animal seemed dead; but upon stopping the orifices of the tubes with our fingers, or strongly pressing or rubbing the abdomen, the animal quickly began to breathe again; and by lifting up the fingers and closing them again, to let out pait of the air included in the thorax, 